\title{
KOMUNIKASI PENDIDIKAN BERBASIS BLENDED LEARNING DALAM MEMBENTUK KEMANDIRIAN BELAJAR
}

\author{
Oleh : Usman \\ (Dosen Tarbiyah IAIN Parepare) \\ usmannoer@gmail.com
}

\begin{abstract}
Abstrak
Komunikasi Pendidikan menjadi salah satu keilmuan yang dilakukan dalam rangka peningkatan di dunia pendidikan. Salah satu modelnya yaitu Blended Learning yaitu suatu komunikasi pembelajaran yang menggabungkan penerapan pembelajaran tradisional di dalam kelas dengan pembelajaran online yang memanfaatkan teknologi informasi. Model pembelajaran ini mengoptimalkan pengintegrasian komunikasi lisan yang ada pada pembelajaran tatap muka dengan komunikasi tertulis pada pembelajaran online. Lebih lanjut pengertian lain dari Blended Learning merupakan pembelajaran yang bersifat fleksibel salain itu penggunaan e-learning atau pembelajaran online merupakan saah satu bentuk contoh pembelajaran yang fleksibel dalam metode Blended Learning. Penerapan model ini mampu meningkatkan mutualitas serta kualitas pembelajaran. Pemblajaran ini dapat menunjukan perbedaan yang lebih baik dalam segi motivasi, minat, maupun hasil belajar peserta didik dibanding metode-metode lain terutama metode dalam pembelajaran langsung, sehingga metode Blended Learning berhasil menjadi trend dan banyak digunakan di perguruan tinggi terkemuka di dunia. Menurut Vernadakis, et al (2012) model pembelajaran Blended Learning mampu menciptakan proses pembelajaran berpusat pada peserta didik. Dalam proses pelaksanaannya, dengan keterlibatan dan partisipasi dalam proses pembelajaran, Blended Learning dapat meningkatkan rasa tanggung jawab peserta didik. Selain itu, adanya interaksi dalam model pembelajaran Blended Learning menciptakan suatu motif kepada peserta didik untuk berkompetisi dalam belajar.
\end{abstract}

\section{Kata Kunci: komunikasi pendidikan, Blended Learning, dan Kemandirian Belajar}

\section{A. Pendahuluan}

Sebagai suatu pilar yang memiliki urgensi dalam rangka menciptakan suasana kehidupan yang lebih baik, maka pendidikan sudah selayaknya dapat menghasilkan pengembangan kompetensi fisik sekaligus juga psikis, hal tersebut termaktub dalam rumusan tujuan pendidikan nasional yang ada dalam undang-undang sistem pendidikan Nsional Indonesia No, 20 tahun 2003 sebagai berikut: Pendidikan Nasional berfungsi mengembangkan kemampuan dan membentuk watak serta peradaban bangsa yang bermartabat, bertujuan untuk berkembangnya potensi peserta didk agar menjadi manusia yang beriman dan bertakwa keapda Tuhan yang Maha Esa, berakhlak mulia, sehat, berilmu, cakap, kreatif, mandiri dan menjadi warga Negara yang demokratis dan bertanggung jawab. 
[Komunikasi Pendidikan Berbasis Blended Learning dalam Membentuk

Pendidikan mengalami perkembangan secara siknifikan dan bertahap pada berbagai aspek pembelalajarannya meliputi sarana dan fasilitas pembelajaran, media, model, strategi dan teknologi yang mendukung dalam pembelajaran serta tenaga pengajaranya.

Pendidikan edentik dengan upaya melakukan transfer pengetahuan dengan merealisasikan program pembelajaran dalam bentuk proses belajar mengajar. Proses kegiatan belajar mengajar merupakan interaksi diantara peserta didik dan guru dalam rangka mencapai tujuan pembelajaran yang telah ditetapkan. Sugihartono dkk (2007: 81) menyatakan bahwa implementasi berbagai model pembelajaran merupakan upaya yang dilakukan dengan sengaja oleh para pendidik untuk menyampaikan ilmu dan pengetahuan, mengorganisasi dan meciptakan sistem lingkungan dengan berbagai metode sehingga peserta didik dapat melakukan kegiatan belajar secara efektif dan efisien dengan hasil yang optimal.

Proses pembelajaran yang efektif akan menjadikan peserta didik dapat aktif selama proses pembelajaran berlangsung. Pembelajaran aktif dapat dilakukan untuk mengelola kelas dengan menggunakan berbagai metode. Guru yang mampu menerapkan berbagai metode belajar yang kreatif, bervariasi dan lebih terfokus dalam mengembangkan peserta didiknya akan menjadikan peserta didik lebih aktif dalam proses pembelajarannya.

Aktivitas belajar adalah kegiatan yang dilakukan dalam proses pembelajaran yakni antara guru dan peserta didiknya dalam rangka mencapai tujuan belajar. Aktivitas yang dilakukan disini adalah berfokus pada peserta didik, sebab dengan adanya ativitas dalam proses pembelajaran menjadikan pembelajaran lebih bermakna. Oleh karenanya aktvitas peserta didik dalam proses pembelajaran merupakan hal penting, karena merupakan ukuran kemampuan untuk memahami pengetahuan dan fungsinya untuk diaktualisasikan, sehingga aktivitas belajar ini penting untuk melibatkan semua komponen dalam proses pendidikan, termasuk didalamnya adalah penggunaan teknologi informasi sebagai media dalam pembelajaran.

Saat ini dunia bergerak cepat menuju terbentuknya suatu masyarakat berbasis sains (science-based society), kegiatan bisnis berbasis ilmu pengetahuan (knowledge based business enterprises), dan terwujudnya suatu budaya baru berlandaskan Ipteks terutama teknologi informasi dan komunikasi (TIK) atau dikenal juga dengan information and communication technology (ICT) yang dengan wujud utamanya adalah internet.

Munculnya teknologi dalam bidang informasi dan komunikasi telah membawa manfaat yang begitu besar bagi kehidupan manusia, teramasuk dunia pendidikan sangat diuntungkan dengan adanya kemajuan dalam bidang teknologi karena manfaatnya yang luar biasa.

Salah satu yang mendapat perhatian penting seiring dengan perkembangan IT (Information Technology) adalah sistem pembelajaran yang mengembangkan pembelajaran berbasis multimedia baik secara online maupun secara offline. Melalui multimedia pembelajaran tidak lagi monoton berpusat pada guru, tetapi lebih bervariasi melalui penggunaan sumber belajar yang bervariasi dan lebih menarik perhatian peserta didik. Secara riil, bentuk dari perkembangan teknoligi informasi dan komunikasi yang telah terimplementasi dalam dunia pendidikan adalah electronic learning, biasa disingkat e-learning.

E-learning merupakan suatu inovasi yang memiliki peran besar dalam proses pembelajaran, dimana proses belajar tidak hanya membantu dalam memahami mamahami materi 
secara komprehensip dalam pembelajaran, tetapi menjadikan pembelajaran lebih mudah dan menyenangkan yakni hanya memilih menu dalam bentuk icon, materi ajar dapat secara cepat ditampilkan. Materi bahan ajar dapat divisualisikan delam berbagai format dan bentuk dinamis dan interaktif. Peserta didik akan termotivasi dalam melakukan proses pembelajaran mulai dari awal pembelajaran, pemberian materi secara interaktif sampai pada tahap evaluasi melibatkan peran teknologi di dalamnya. Bahkan menurut Sagala (2006: 161) pembelajaran dengan cara memanfaatkan berbagai variasi media (multimedia) dengan materi yang menarik dapat meningkatkan antusiasme peserta didik dalam proses pembelajarnnya.

E-learning merupakan model pembelajran online (pembelajaran jarak jauh) yang diharapkan mampu menggeser model pembelajaran konvensional yang dianggap selama ini memiliki berbagai kekurangan. Namun demikian, dalam iplementasinya model pembelajaran elearning memiliki serangkain keterbatasan dibandingkan dengan pembelajaran secara tatap muka di kelas (face-to-face learning). Keterbatasan tersebut meliputi; lemahnya kontrol disebabkan oleh kurangnya penguasaan konsep metode penggunaan aplikasi e learnig baik oleh para pendidikan maupun para perserta didiknya, keterbatasan akses jaringan internet, ketersediaan modul pembelajaran serta masih kurannya infrastruktur lainnya oleh para perserta didik.

Oleh karenanya, berbagai kompromi ditawarkan sebagai solusi alternatif yakni dengan memadukan antara model pembelajaran yang bersifat tatap muka di kelas (face-to-face) dengan model pembelajaran berbasis e-learning.

Blended Learning adalah suatu pembelajaran yang manggabungkan penerapan pembelajaran tradisional di dalam kelas dengan pembelajaran online yang memanfaatkan teknologi informasi. Menurut Garrison \& Vaughan (2008) dengan mengoptimalkan pengintegrasian komunikasi lisan yang ada pada pembelajaran tatap muka dengan komunikasi tertulis pada pembelajaran online adalah konsep dasar model pembelajaran Blended Learning. Lebih lanjut pengertian lain dari Blended Learning merupakan pembelajaran yang bersifat fleksibel salain itu penggunaan e-learning atau pembelajaran online merupakan saah satu bentuk contoh pembelajaran yang fleksibel dalam metode Blended Learning (Syarif, 2012). Hingga penerapan model ini mampu meningkatkan mutualitas serta kualitas pembelajaran. Pembelajaran ini dapat menunjukan perbedaan yang lebih baik dalam segi motivasi, minat, maupun hasil belajar peserta didik dibanding metode-metode lain terutama metode dalam pembelajaran langsung (Syarif, 2012; Sjukur, 2012; Hermawanto, Kusairi, \& Wartono, 2013). sehingga metode Blended Learning berhasil menjadi trend dan banyak digunakan di perguruan tinggi terkemuka di dunia.

Namun pembelajaran bukan semata bertumpu pada teknologi sebab pembelajaran pada hakikatnya lebih pada proses interaksi antara guru, peserta didik dan sumber belajar. Meskipun e-learning bisa digunakan secara mandiri oleh peserta didik, namun eksistensi guru menjadi sangat berarti sebagai orang dewasa yang berfungsi memberi dukungan dan mendampingi peserta didik dalam proses pembelajaran (Plummer dalam Sudarwan Danim 2012: 1). Dengan kata lain bahwa proses tatap muka menjadi hal yang penting dan tidak boleh ditinggalkan dalam pembelajaran. Oleh karena itu model pembelajaran yang menggabungkan (blending) metode face to face learning dengan e-learning secara integratif dan sistematis akan membuat proses pembelajaran menjadi lebih bermakna. 


\section{B. Multimedia Berbasis Blended Learning}

Penggunaan apalikasi teknologi informasi (e-learning) sebagai media pembelajaran sudah semakin sering ditemui dalam pendidikan. Konsep e-learning tentunya memberi nuansa baru bagi proses pendidikan yang selama ini hanya bertumpu pada eksistensi guru. Menurut Mayer (2008: 10) bahwa e-learning adalah pembelajaran yang disajikan dengan bantuan komputer. Huruf "e" dalam e-learning bermakna bahwa materi yang diberikan berbentuk digital sehingga dapat disimpan dalam perangkat elektonik. E-learning memberi ilustrasi bahwa dengan adanya teknologi informasi dan komunikasi, khususnya internet, pembelajaran menjadi lebih terbuka (open) dan fleksibel (flexible), terjadi kapan saja, dimana saja dan dengan dan kepada siapa saja di lokasi mana saja (distributed), berbasis komunitas.

Menurut Castle and McGuire dalam Syarif, (2010: 36), elearning mampu meningkatkan pengalaman belajar sebab peserta didik dapat belajar dimanapun dan dalam kondisi apapun selama dirinya terhubung dengan internet tanpa harus mengikuti pembelajaran tatap muka (face to face learning). Blended learning adalah suatu pendekatan yang fleksibel untuk merancang program yang mendukung campuran dari berbagai waktu dan tempat untuk belajar.

Menurut Rovai and Jordan dalam Udin Saefudin Sa'ud, (2004: 3) model blended learning pada dasarnya merupakan gabungan keunggulan pembelajaran yang dilakukan secara tatap muka (face to face learning) dan secara virtual (e-learning). Pembelajaran online atau $e$ learning dalam blended learning menjadi perpanjangan alami dari pembelajaran ruang kelas tradisional yang menggunakan model tatap muka (face to face learning). Lewat model blended learning, proses pembelajaran akan lebih efektif karena proses belajar mengajar yang biasa dilakukan (conventional) akan dibantu dengan pembelajaran secara e-learning yang dalam hal ini berdiri di atas infrastruktur teknologi informasi dan bisa dilakukan kapanpun dan dimanapun, blended learning bukan hanya mengurangi jarak yang selama ini ada diantara peserta didik dan guru namun juga meningkatkan interaksi diantara kedua belah pihak. Berdasarkan proportion of content delivered online, Allen dkk (2007: 5) memberikan kategorisasi yang jelas terhadap blended learning, traditional learning, web facilitated dan online learning.

1. Karakteristik Blended Learning

Adapun karakteristik Blended Learning menurut Jhon Watson, (2008). yaitu :

1.1 Pembelajaran yang menggabungkan berbagai cara penyampaian, model pengajaran, gaya pembelajaran, serta berbagai media berbasis teknologi yang beragam

1.2 Sebagai sebuah kombinasi pengajaran langsung (face-to-face), belajar mandiri, dan belajar mandiri via online.

1.3 Pembelajaran yang didukung oleh kombinasi efektif dari cara penyampaian, cara mengajar dan gaya pembelajaran.

1.4 Guru dan orangtua pembelajar memiliki peran yang sama penting, guru sebagai fasilitator, dan orangtua sebagai pendukung.

2. Tujuan Blended Learning

2.1 Membantu peserta didik untuk berkembang lebih baik di dalam proses belajar, sesuai dengan gaya belajar dan preferensi dalam belajar.

2.2 Menyediakan peluang yang praktis realistis bagi guru dan peserta didik untuk pembelajaran secara mandiri, bermanfaat, dan terus berkembang. 
2.3 Peningkatan fleksibilitas bagi peserta didik, dengan menggabungkan aspek terbaik dari tatap muka dan instruksi online. Kelas tatap muka dapat digunakan untuk melibatkan para peserta didik dalam pengalaman interaktif. Sedangkan porsi online memberikan peserta didik dengan konten multimedia pada setiap saat, dan di mana saja selama masih memiliki akses Internet.

3. Manfaat Blended Learning

3.1 Proses belajar mengajar tidak hanya tatap muka saja, tetapi ada penambahan waktu pembelajaran dengan memanfaatkan media online.

3.2 Mempermudah dan mempercepat proses komunikasi antara guru dan peserta didik (mitra belajar).

3.3 Membantu memotivasi keaktifan peserta didik untuk ikut terlibat dalam proses pembelajaran. Hal ini akan membentuk sikap kemandirian belajar pada peserta didik.

3.4 Meningkatkan kemudahan belajar sehingga peserta didik menjadi puas dalam belajar

4. Kelebihan dan Kekurangan Blended Learning

Kelebihan Blended Learning :

4.1 Dapat digunakan untuk menyampaikan pembelajaran kapan saja dan dimana saja.

4.2 Pembelajaran terjadi secara mandiri dan konvensional, yang keduanya memiliki kelebihan yang dapat saling melengkapi.

4.3 Pembelajaran lebih efektif dan efisien

4.4 Meningkatkan aksesbilitas. Dengan adanya Blended Learning maka pembelajar semakin mudah dalam mengakses materi pembelajaran.

4.5 Pembelajaran menjadi lebih luwes dan tidak kaku.

Kekurangan Blended Learning :

4.1 Media yang dibutuhkan sangat beragam, sehingga sulit diterapkan apabila sarana dan prasarana tidak mendukung.

4.2 Tidak meratanya fasilitas yang dimiliki pebelajar, seperti komputer dan akses Internet. Padahal dalam Blended Learning diperlukan akses Internet yang memadai, apabila jaringan kurang memadai akan menyulitkan peserta dalam mengikuti pembelajaran mandiri via online.

4.3 Kurangnya pengetahuan masyarakat terhadap penggunaan teknologi

4.4 Tidak meratanya fasilitas yang dimiliki pelajar, seperti komputer dan akses Internet

4.5 Membutuhkan strategi pembelajaran yang tepat untuk dapat memaksimalkan potensi dari Blended Learning.

5. Proses perancangan Blended Learning

Menurut Jared M. Carmen dalam Charles \& Graham (2005: 2), seorang President Aglint Learning menyebutkan lima kunci dalam merancang Blended Learning. Adapun ke-5 kunci tersebut yaitu:

a. Live Event

Pembelajaran langsung atau tatap muka (instructor-led instruction) secara terpadu dalam waktu dan tempat yang sama (classroom) ataupun waktu sama tapi tempat berbeda (seperti virtual classroom). Bagi beberapa orang tertentu, pola pembelajaran langsung seperti ini masih menjadi pola utama. Namun demikian, pola pembelajaran langsung inipun perlu didesain sedemikian rupa untuk mencapai tujuan sesuai kebutuhan.

b. Self-Paced Learning

Mengkombinasikan pembelajaran konvensional dengan pembelajaran mandiri (self-paced learning) yang memungkinkan peserta didik belajar kapan saja, dimana saja dengan 
menggunakan berbagai konten (bahan belajar) yang dirancang khusus untuk belajar mandiri baik yang bersifat text-based maupun multimedia-based (video, animasi, simulasi, gambar, audio, atau kombinasi dari kesemuanya). Bahan belajar tersebut, dalam konteks saat ini dapat dikirim secara online (via web maupun via mobile device dalam bentuk streaming audio, streaming video, e-book, dll) maupun offline (dalam bentuk $\mathrm{CD}$, cetak, dll).

c. Collaboration

Mengkombinasikan kolaborasi, baik kolaborasi pengajar, maupun kolaborasi antar peserta didik yang kedua-duanya bisa lintas sekolah/kampus. Dengan demikian, perancang Blended Learning harus meramu bentuk-bentuk kolaborasi, baik kolaborasi antar peserta didik ataupun kolaborasi antara peserta didik dan pengajar melalui alat-alat komunikasi yang memungkinkan seperti chatroom, forum diskusi, email, website/webblog, mobile phone. Tentu saja kolaborasi diarahkan untuk terjadinya konstruksi pengetahuan dan keterampilan melalui proses sosial atau interaksi sosial dengan orang lain, bisa untuk pendalaman materi, problem solving, project-based learning, dll.

d. Assessment

Tentu saja dalam proses pembelajaran jangan lupakan cara untuk mengukur keberhasilan belajar (teknik assessment). Dalam Blended Learning, perancang harus mampu meramu kombinasi jenis assessment baik yang bersifat tes maupun non-tes, atau tes yang lebih bersifat otentik (authentic assessment/portfolio) dalam bentuk project, produk dll. Disamping itu, juga pelru mempertimbangkan antara bentuk-bentuk assessment online dan assessment offline. Sehingga memberikan kemudahan dan fleksibilitas peserta belajar mengikuti atau melakukan assessment tersebut.

e. Performance Support Materials

Ini bagian yang jangan sampai terlupakan ketika akan mengkombinasikan antara pembelajaran tatap muka dalam kelas dan tatap muka virtual, pastikan kesiapan sumber daya untuk mendukung hal tersebut. Bahan belajar disiapkan dalam bentuk digital, apakah bahan belajar tersebut dapat diakses oleh peserta belajar baik secara offline (dalam bentuk CD, MP3, DVD, dll) maupun secara online (via website resemi tertentu). Jika pembelajaran online dibantu dengan suatu Learning/Content Management System (LCMS), pastikan juga bahwa aplikasi sistem ini telah terinstal dengan baik, mudah diakses, dan lain sebagainya.

\section{Pengembangan Pembelajaran Berbasis Blended Learning}

Berbagai konsep dan teknik baru dalam pembelajaran telah banyak dikembangkan untuk memperbaiki proses pembelajaran. Oleh karena itu, dibutuhkan suatu model pembelajaran variatif yang dapat merangsang aktivitas peserta didik dalam mengikuti proses pembelajaran, sehingga peserta didik akan berperan aktif dan memberikan feedback yang positif. Solusi pembelajaran yang diharapkan harus mampu memberikan peningkatan terhadap aktivitas peserta didik. Pembelajaran yang dapat meningkatkan aktivitas peserta didik dalam proses pembelajaran adalah Blended Learning. Pembelajaran Blended Learning memberikan kesempatan kepada peserta didik untuk menjadi pembelajar aktif yang memahami kebutuhan dirinya dan mengupayakan pencapaian pemahaman akan pengetahuan secara mandiri.

Model pembelajaran Blended Learning memberikan kesempatan kepada peserta didik untuk mengembangkan kemampuan individu tanpa meninggalkan interaksi sosial di dalam kelas, 
sehingga dengan sistem ini peserta didik lebih berperan aktif dalam pembelajaran sedangkan guru sebagai fasilitator.

Srisakdi (2006: 55) menyebutkan bahwa konsep dalam pengembangan pembelajaran digunakan model penggabungan (blended learning), Model dianggap memberikan solusi dalam penggembngan pembelajaran pada institusi yang masih menerapkan pembelajaran elektronik yang menyambung pada internet (online) sebagai tolak ukur aktivitas, secara konsep, pengembangan didasarkan pada model-model pembelajaran.

Darsono (2000: 15) mengemukakan bahwa konsep pembelajaran secara rinci dijabarkan mulai dari pembelajaran tradisional hingga pembelajaran elektronik yang menyambung pada internet (online). Model pembelajaran penggabungan (blended learning) yang dikembangkan mengacu pada pengembangan pembelajaran-pembelajaran elektronik yang menyambung pada internet (online) bukan lagi sebagai pelengkap atau pengganti kegiatan pembelajaran. Tatap muka, diskusi, forum, dan lain-lain semuanya dilakukan secara sistematis dan terintegrasi pada web yang dikembangkan.

Secara teknis pengembangan pembelajaran model penggabungan (blended) merupakan model kombinasi pembelajaran yang dilakukan dalam konteks tatap muka, pembelajaran elektronik yang menyambung pada internet (online) dan pembelajaran elektronik yang tidak menyambung pada internet (offline).

Proses pembelajaran tatap muka disebut juga masa pengenalan. Pada masa pengenalan berlangsung proses pembelajaran tatap muka pembelajaran elektronik yang tidak menyambung pada internet (offline) atau bertemu dalam kelas nyata. Kegiatan di kelas nyata adalah dosen menyampaikan satu penjelasan secara teknis penggunaan sistem pembelajaran berbasis web dan peserta didik mendengarkan, menyimak dan mempraktikkan petunjuk penggunaan yang telah disediakan.

Model pengembangan penggabungan (blended) yang dikembangkan oleh Srisakdi (2006: 11), mengacu pada definisi-definisi yang telah digambarkan oleh tabel 1. sehingga pengembangan pembelajaran elektronik yang menggunakan internet bukan lagi sebagai pelengkap atau pengganti setiap kegiatan pembelajran. Tatap muka, diskusi, forum dll semuanya dilakukan secara sistematis dan terintegrasi pada web yang dikembangkan.

\section{Tabel Model-Model Pembelajaran}

\begin{tabular}{|l|l|l|}
\hline Deskripsi & Model & $\begin{array}{l}\text { Presentasi bahan ajar } \\
\text { berbasis web }\end{array}$ \\
\hline $\begin{array}{l}\text { Pembelajaran tanpa memanfaatkan fasilitas } \\
\text { pembelajaran elektronik yang menyambung } \\
\text { pada internet (online) }\end{array}$ & $\begin{array}{l}\text { Tradisional } \\
\text { (traditional) }\end{array}$ & $0 \%$ \\
\hline Pemanfaatan web dalam proses pembelajaran & Fasilitas web (web & $1-29 \%$ \\
\hline
\end{tabular}


[Komunikasi Pendidikan Berbasis Blended Learning dalam Membentuk

untuk membantu peningkatan penguasaan facilitated)

bahan ajar yang tidak terpenuhi dalam proses

tatap muka.Pemanfaatan lebih banyak pada pengumpulan tugas.

Proses pembelajaran menggunakan kombinasi

antara bahan ajar berbasis web dan tatap muka.

Dalam proses pembelajaran, interaksi (forum

diskusi) lebih banyak dilakukan

Seluruh proses pembelajaran melalui

pembelajaran elektronik yang

menyambung pada internet (online).

Tidak ada pembelajaran tatap muka

Selanjutnya Srisakdi (2006: 53) menyatakan bahwa dalam masa belajar mandiri. Peserta didik akan berkumpul dan bertemu beberapa kali dengan guru di web atau bertemu langsung sesuai jadwal yang telah ditentukan. Proses tatap muka di tujukan untuk memfasilitasi setiap permasalahan peserta didik yang dihadapi selama proses pembelajaranya.

Pengembangan Blended Learning juga mengarah pada bahan ajar yang digunakan salah satunya berupa modul dalam kemasan elektronik. Dalam pembelajaran berbasis web model elektronik dikenal dengan istilah bahan ajar mandiri atau bahan ajar yang dikemas untuk peserta didik belajar sendiri secara mandiri. Didalam bahan ajar mandiri selain materi juga sudah ada latihan-latihan yang harus dikerjakan peserta didik untuk mengukur perkembangan belajarnya, dalam pembelajaran penggabugan (blended), selain bahan ajar modul elektronik

Pengembangan bahan ajar yang lain adalah pemanfaatan media atau teknologi. Salah satu ciri dalam proses pembelajaran berbasis web, diantaranya pemanfaatan teks, audio, video, dan multimedia adalah untuk pengayaan materi untuk berlatih dan untuk penguatan peserta didik dalam mempelajari slah satu topik. Dalam pembelajaran penggabungan (blended learning), pengemasan dilakukan secara digital dan diakses melalui bahan ajar berbasis web, pemanfaatan teks, audio, video dan multimedia dilakukan pada masa belajar mandiri. Materi yang dikemas dengan menggunakan teks, audio, video, dan multimedia tersebut dikemas dengan media penyimpanan tertentu.

Menurut Kaye Thorne $(2003 ; 8)$ bahwa saat ini tidak ada metode pembelajaran tunggal yang ideal untuk semua jenis pembelajaran dan pelatihan karena setiap teknologi memiliki keunggulan masing-masing. Teknologi cetak memiliki keunggulan yang sangat fleksibel sebagai sumber belajar, dapat dibawa kemana-mana tanpa menggunakan saluran listrik, sedangkan komputer memiliki keunggulan yang sangat interaktif yakni berupa teks, gambar, film, animasi, dan dapat di konversi dalam berbagai bentuk digital tetapi mobilitasnya terbatas karena bergantung pada satu daya listrik, pada kasus tertentu pembelajaran melalui audio lebih efektif dibandingkan dengan video. Jadi masing-masing teknologi mempunyai keunggulan untuk belajar tertentu, untuk karakteristik bidang tertentu. Demikian juga metode pembelajaran untuk peserta didik disekolah dasar dapat efektif tetapi tidak untuk peserta didik pasca sarjana demikian pula 
sebaliknya, oleh sebab itu, diperlukan metode pembelajaran yang berbeda untuk karakteristik pembelajaran yang berbeda.

Sebagai sarana pembelajaran terpenting dalam pembelajaran elektronik yang menyambung pada internet (online) pengembangan pembelajaran penggabungan (blended learning), penggunaan teknologi web diperlukan dalam pembelajaran untuk melakukan tatap muka, penyimpanan file, diskusi, pemantauan dan lain-lain. Dengan model pembelajaran berbasis blended learning diharapkan porsi waktu masa pembelajaran mandiri lebih banyak dibandingkan dengan tatap muka baik pembelajaran elektronik yang tidak menyambung pada internet (offline) maupun pembelajaran elektronik yang menyambung pada internet (online).

Dalam pembelajaran berbasis penggabungan (blended learning), peserta didik tidak hanya mengakses bahan ajar, melainkan melakukan beberapa aktivitas : 1) melakukan interaksi, baik melalui surat elektronik (email), obrolan (chat), ataupun forum diskusi. Peserta didik dapat bertanya maupun mengajukan pertanyaan dan pendapat tentang suatu hal baik dengan guru maupun dengan temanya sendiri, 2) mengerjakan tugas atau assignments. Peserta didik akan mendapatkan tugas baik perseorangan ataupun kelompok, 3) menjawab soal latihan, setiap topik akan disediakan beberapa soal latihan yang harus di jawab peserta didik. 4) berkomunikasi dengan ahli bidang ilmu dinegara lain melalui internet.

Salah satu model pembelajaran adalah Blended Learning. M.Yusuf T. (2011: 232-242) mendefinisikan Blended Learning sebagai integrasi antara face to face dan online learning untuk membantu pengalaman kelas dengan mengembangkan teknologi informasi dan komunikasi.

Thorne dalam Sulihin B. Sjukur (2012: 368-378), mendefinisikan Blended Learning sebagai berikut: it represents an opportunity to integrate the innovative and technological advances offered by online learning with the interaction and participation offered in the best of traditional learning. Definisi di atas mengandung makna bahwa Blended Learning menggambarkan sebuah kesempatan yang mengintegrasikan inovasi dan keuntungan teknologi pada pembelajaran online dengan interaksi dan partisipasi dari keuntungan pembelajaran tatap muka.

Sementara itu, Uwes A.Chaeruman dalam Dian Wahyuningsih (2013: 40), menjelaskan Blended Learning sebagai pembelajaran yang mengkombinasikan setting pembelajaran synchronous dan asynchronous secara tepat guna untuk mencapai tujuan pembelajaran. Beberapa definisi di atas, memberikan gambaran bahwa Blended Learning merupakan kombinasi antara pembelajaran tatap muka dan pembelajaran online dengan bantuan teknologi informasi dan komunikasi secara tepat guna untuk mencapai tujuan pembelajaran. Pembelajaran synchronous adalah kegiatan pembelajaran yang dilakukan pada waktu yang sama dan tempat yang sama ataupun berbeda, sedangkan pembelajaran asynchronous adalah kegiatan pembelajaran yang dilakukan pada waktu dan tempat yang berbeda.

Selanjutnya Dian Wahyuningsih mendefinisikan Blended Learning dengan pendekatan konstruktif. Blended Learning by constructive approach (BLCA) terdiri atas dua istilah, yaitu Blended Learning (pembelajaran bercampur) dan constructive approach (pendekatan konstruktif). Beberapa definisi dari ahli di atas memberikan gambaran bahwa Blended Learning merupakan kombinasi antara pembelajaran tatap muka dengan pembelajaran online dengan bantuan teknologi informasi dan komunikasi. 
Aspek yang digabungkan dalam Blended Learning tidak hanya mengkombinasikan faceto-face dan online learning saja tetapi juga dapat berbentuk apa saja, seperti: metode, media, sumber, lingkungan ataupun strategi pembelajaran. Berdasarkan proportion of content delivered online, Allen dkk (2017: 5) memberikan kategorisasi yang jelas terhadap Blended Learning, traditional learning, web facilitated, dan online learning

Begitu banyaknya informasi yang dapat diserap peserta didik, baik saat di rumah atau di sekolah bahkan di mana pun peserta didik berada dan kapanpun. Apa lagi kini media tidak melulu harus menggunakan komputer yang ada di atas meja yang teronggok kaku, berat untuk dipindahkan. Kini tersedia beberapa pilihan, ada laptop, ada komputer tablet, bahkan ada smartphone. Jika dulu sumber belajar terorganisir dalam sebuah buku atau media lain yang bersifat tetap, kini tersedia berjuta informasi melalui internet.

Media pembelajaran yang baik harus memenuhi beberapa syarat. Media pembelajaran harus meningkatkan motivasi pembelajar. Penggunaan media mempunyai tujuan memberikan motivasi kepada pembelajar. Selain itu media juga harus merangsang pembelajar mengingat apa yang sudah dipelajari selain memberikan rangsangan belajar baru. Media yang baik juga akan mengaktifkan pembelajar dalam memberikan tanggapan, umpan balik dan juga mendorong pembelajar untuk melakukan praktik-praktik dengan benar.

Peserta didik dan guru dapat meningkatkan pembelajran di kelas dengan mengakses informasi dari berbagai sumber (database, perpustakaan, kelompok minat khusus), berkomunikasi melalui komputer dengan peserta didik lain atau dengan para ahli di bidang studi tertentu, dan saling bertukar informasi. Kegiatan seperti yang dilakukan oleh geografis nasional memungkinkan peserta didik dan guru bersama-sama untuk menuai keuntungan dari menghubungkan jaringan nasional peserta didik, guru, dan ilmuwan untuk menyelidiki berbagai topik.

Teknologi Informasi menurut Richard Weiner dalam Websters New Word Dictinonary and Communication disebutkan bahwa Teknologi Informasi adalah pemprosesan, pengolahan, dan penyebaran sata oleh kombinasi komputer dan telekomunikasi.

\section{Kemandirian Belajar dalam Blended Learning}

Menurut Vernadakis, et al (2012) model pembelajaran Blended Learning mampu menciptakan proses pembelajaran berpusat pada peserta didik. Dalam proses pelaksanaannya, dengan keterlibatan dan partisipasi dalam proses pembelajaran, Blended Learning dapat meningkatkan rasa tanggung jawab peserta didik. Selain itu, adanya interaksi dalam model pembelajaran Blended Learning menciptakan suatu motif kepada peserta didik untuk berkompetisi dalam belajar.

Pembelajaran dengan model blended learning mampu menggeser prinsip pembelajaran dari teacher center menuju student center secara dinamis. Pembelajaran model blended learning bersifat saling melengkapi kekurang pembelajaran model face to face learning dan e-learning, sebab menurut Munir (2009: 176) kelemahan pembelajaran eelearning diantaranya peserta didik dan guru terpisah secara fisik sehingga interaksi secara tatap muka menjadi berkurang. Selain itu e-elearning cenderung pada pelatihan daripada pendidikan yang mengarah pada kemampuan kognitif dan psikomotirk dan kurang memperhatikan aspek afektif. Lewat face to face learning 
guru mampu memfungsikan dirinya sebagai pendidik dan memberikan dorongan motivasi secara langsung dan ekspresif pada peserta didik. Model blended learning membuat aktifitas peserta didik dalam kelas menjadi lebih variatif. Peserta didik tidak hanya bertumpu pada informasi yang disampaikan oleh guru, namun berusaha mengupayakan informasi dari berbagai sumber.

Jika diperhatikan lebih seksama, sikap bertanggung jawab terhadap tugas dalam pembelajaran merupakan salah satu indikator dari kemandirian belajar peserta didik. Hal ini dijelaskan oleh Zumbrunn, Tadlock, \& Roberts (2011) yang menyatakan bahwa peserta didik yang mandiri dalam belajar mempunyai tanggung jawab untuk memonitor dirinya sendiri dalam segi apapun, baik dalam mencapai sebuah tujuan, maupun dalam kefokusan terhadap apa yang ditugaskan kepadanya. Menurut Zimmerman (2002) peserta didik yang mandiri adalah peserta didik yang aktif dalam mengarahkan proses-proses metakognitif, motivasi dan tingkah laku pada saat proses pembelajaran. Lebih lanjut, kemampuan metakognitif diartikan sebagai kesadaran berpikir tentang apa yang diketahui dan apa yang tidak diketahui. Kemandirian belajar peserta didik diindikasikan dengan kemampuan peserta didik dalam mengetahui bagaimana cara mereka belajar, dan mengetahui strategi belajar yang digunakan sehingga proses pembelajaran akan lebih menuai hasil yang optimal.

Beberapa penelitian yang menggunakan model pembelajaran Blended Learning antara lain adalah Lucy Barnard, et al (2009) yang berhasil mengidentifikasi bahwa model pembelajaran Blended Learning berpotensial untuk memfasilitasi kemandirian belajar peserta didik, disamping itu beberapa penelitian lain juga yang telah membuktikan bahwa metode ini dapat berpengaruh baik dalam hal kemandirian.

Keberhasilan peserta didik dalam belajar ditentukan oleh Kemandirian belajar dari masing-masing individu. Menurut Sudjana (2013) kemampuan-kemampuan peserta didik yang dicapai setelah pengalaman belajar merupakan hasil belajar. Slameto (2015) menambahkan bahwa hasil belajar adalah suatu perubahan yang terjadi secara terus menerus terhadap tingkah laku dan bersifat tidak statis.

Seperti yang sudah dibahas pada model pembelajaran tatap muka, dalam masalah pembelajaran berbasis web selama ini, akan tetap ada pertemuan dengan guru, pada pertemuan tersebut peserta didik dapat menyampaikan beberapa permasalahan selama proses belajar, baik itu terkait bahan ajar ataupun permasalah yang terkait dengan koneksi internet. Setelah peserta didik menyelesaikan masa belajar mandiri pada minggu terakhir dan diakhiri dengan ujian semester.

\section{E. Kesimpulan}

Secara umum dapat disimpulkan bahwa dalam pembelajaran penggabungan (blended learning), proses pembelajaran berlangsung menggunakan empat model kombinasi yakni: tatap muka, media elektronik, teks, audio, video, dan multimedia serta berbasis web. Porsi belajar mandiri dengan pembelajaran menggunakan web memiliki komposisi yang sama dengan proses tatap muka.

Pembelajaran Blended Learning fokus utamanya adalah pelajar. Pelajar harus mandiri pada waktu tertentu dan bertanggung jawab untuk pembelajarannya. Suasana pembelajaran Blended Learningakan mengharuskan peserta didik memainkan peranan yang lebih aktif dalam pembelajarannya. Peserta didik membuat perancangan dan mencari materi dengan usaha dan inisiatif sendiri. Blended Learning ini tidak berarti menggantikan model belajar konvensional di 
[Komunikasi Pendidikan Berbasis Blended Learning dalam Membentuk

Kemandirian Belajar]

dalam kelas, tetapi memperkuat model belajar tersebut melalui pengembangan teknologi pendidikan. 


\section{DAFTAR PUSTAKA}

Allen, IE, Seamen, J. \& Garret, R. Blending in: The Extent and Promise of Blended Education in the United States. USA: The Sloan Consortium, 2007

Carman, J.A. 2005. Blended learning Design: Five Key Ingredients. (Online). (http://www.agilantlearning.com/pdf/Blended-Learning-Design.pdf/, diakses tanggal 1 Juni 2018).

Chaeruman, U.A. 2008. Contoh Penerapan Blended learning. (Online). (http:// www.teknologipendidikan.net_files/Contoh-Penerapan-Blended-Learning; diakses tanggal 1 Juni 2018).

Chaeruman, U.A. 2011. Implementing Blended Learning: A Case Based Sharing Experience. http://www.teknologipendidikan.net/2011/06/21/ implementing-blended-learning-acase-based-sharing-experience/ pada tanggal 25 Juni 2018.

Curtis J. Bonk, Charles R \& Graham. (2006). The Handbook of Blended Learning.bUSA : Preiffer

Danim, Sudarwan, Media Komunikasi Pendidikan: Pelayanan Profesional Pembelajaran dan Mutu Hasil Belajar Proses Belajar Mengajar di Perguruan Tinggi Jakarta: Bumi Aksara, 1995

Darsono, Belajar \& Pembelajaran, Semarang : CV IKIP Semarang Press, 2000

Depdiknas. 2008. Pembelajaran Tatap Muka, Penugasan Terstruktur, dan Kegiatan Mandiri Tidak Terstruktur. Jakarta: Direktorat Pembinaan Sekolah Menengah Atas.

E. Mayer, Richard. (2009). Multimedia Learning;Prinsip-prinsip dan aplikasi. ITS Press.

Garrison, D. R., \& Vaughan, N. D. (2008). Blended Learning in Higher Education : Framework, principles and guidelines. San Fransisco: Josey-Bass.

Garrison, D.R. \& Vaughan, N.D. 2008. Blended learning in Higher Education. San Francisco: Jossey-Bass.

Graham, C.R. 2005. Blended learning system: Definition, current trends and future direction. In: Bonk, C.J., Graham, C.R. (eds.) Handbook of Blended learning: Global Perspectives, Local Designs, pp.3-21. San Francisco: Pfeiffer.

Graham, Charles R, 2004 . Blended Learning Systems: Definition, Current Trends, and Future Directions. http://www.publicationshare.com/ grahamintro, Diakses pada tanggal 12 Juni 2018.

Hermawanto, Kusairi, S., \& Wartono. (2013). Pengaruh Blended Learning terhadap Penguasaan Konsep dan Penalaran Fisika Peserta Didik Kelas X. Jurnal Pendidikan Fisika Indonesia, 67-76.

Kaye Thorne and David Mackey, Everything You Ever Needed to Know About Training, (London: Kogan Page Publishers, 2007), 
Lucy Barnard, Y.Lan, W., M.To, Y., OslandPaton, V., \& Shu-LingLai. (2009). Measuring selfregulation in online and blended learning environments. The Internet and Higher Education, 1-6.

Mayer, R.E. 2009. Multimedia learning: Prinsipprinsip dan aplikasi. (Terjemahan Baroto Tavip Indrojarwo) Yogyakarta: Pustaka Pelajar. (Buku asli diterbitkan tahun 1999)

McGrath, A. L. (2014). Content, Affective, and Behavioral Challenges to Learning: Students' Experiences Learning Statistics. International Journal for the Scholarship of Teaching and Learning, 1-21.

Munir. 2009. Pembelajaran Jarak Jauh Berbasis Teknologi Informasi dan Komunikasi. Bandung: Alfabeta.

Ningsih, Y. L., \& Jayanti. (2016). Hasil Belajar Mahasiswa Melalui Penerapan Model Blended Learning Pada Mata Kuliah Persamaan Diferensial . Jurnal Pendidikan Matematika JPM RAFA, 1-11.

Noer, M. 2010. Blended learning Mengubah Cara Kita Belajar di Masa Depan. (Online). (http://www.muhammadnoer.com/2010/07/blended-learning-mengubah-cara-kitabelajar-di-masa-depan, diakses tanggal 1 Juni 2018).

Sa'ud, Udin Saefudin, Inovasi Pendidikan Bandung: AlfaBeta, 2008

Sagala, Syaiful, Konsep dan Makna Pembelajaran Bandung: Penerbit Alfabeta. 2006

Sjukur, S.B. 2012. Pengaruh Blended Learning terhadap Motivasi Belajar dan Hasil Belajar Siswa Tingkat SMK. Jurnal Pendidikan Vokasi. Nomor 3. Volume 2

Slameto. (2015). Belajar dan Faktor-faktor yang Mempengaruhinya. Jakarta: Rineka Cipta.

Srisakdi, Pedoman Pengembangan Bahan Ajar Berbasis web, Departemen Pendidikan Nasional, 2006 , h.55

Sudjana, N. (2013). Penilaian Hasil Proses Belajar Mengajar. Bandung: Remaja Rosdakarya.

Sugihartono, dkk. Psikologi Pendidikan. Yogyakarta: UNY Press. 2007

Suprijono, Agus, Coopertaive Learning Teori dan Aplikasi PAIKEM. Yogyakarta: Pustaka Belajar. 2012

Syarif, I. (2012). Pengaruh Model Blended Learning Terhadap Motivasi Dan Prestasi Belajar Siswa SMK. Jurnal Pendidikan Vokasi, 234-249.

Thorne, Kaye, How To Integrate Online And Traditional Learning, London : Kogan Page, 2003

Undang-Undang Republik Indonesia Nomor 20 Tahun 2003 tentang Sistem Pendidikan Nasional.

Vernadakis, N., Giannousi, M., Derri, V., Michalopoulos, M., \& Kioumourtzoglou, E. (2012). The impact of blended and traditional instruction in students performance. Procedia Technology 1, pp. 439-443.

Wahyuningsih, Dian. 2013. Implementasi Blended Learning By The Constructive Approach BLCA untuk Meningkatkan Pemahaman Konsep dan Kemandirian Belajar 
Mahasiswa dalam Matakuliah Interaksi Manusia dan Komputer Prodi Teknologi Pendidikan FIP UNY. Thesis, Yogyakarta: Universitas Negeri Yogyakarta.2013

Watson, Jhon . 2008 . Blended Learning : The Converge of Online and Face-to-Face Education. Diambil dari http://www.inacol.org/cms/wp-content/uploads/2012/09/NACOL_PPBlendedLearning-lr.pdf pada tanggal 16 Juni 2018.

Yusuf, T, M.. Mengenal Blended Learning. Jurnal Lentera Pendidikan. No. 2. Volume 14 Desember 2011

Zimmerman, B. J. (2002). Becoming a Self-Regulated Learner: An Overview. Theory Into Practice, 64-70.

Zumbrunn, S., Tadlock, J., \& Roberts, E. D. (2011). Encouraging Self-Regulated Learning in the Classroom: A Review of the Literature . Virginia: Virginia Commonwealth University 